\title{
ANALISIS STUDI KOMPARATIF TENTANG PENERAPAN TRADISIONAL COSTING CONCEPT DENGAN ACTIVITY BASED COSTING (STUDI KASUS PADA RUMAH SAKIT SILOAM DI MANADO)
}

\author{
Olivia H.S. Sumendap \\ David Paul Elia Saerang \\ Sifrid Sonny Pangemanan
}

\author{
Fakultas Ekonomi Dan Bisnis Jurusan Akuntansi \\ Universita Sam Ratulangi Manado \\ Email: oliviaheidy@yahoo.com
}

\begin{abstract}
ABSTRAK
Penelitian ini membandingkan perhitungan biaya metode tradisional dengan perhitungan biaya berdasarkan aktivity $(\mathrm{ABC})$ dalam menentukan tarif kamar rawat inap pada Rumah Sakit Siloam di Manado. Penelitian ini menggunakan metode analisis deskriptif. Data diperoleh dengan menganalisa dokumen, observasi partisipan, serta wawancara dengan kepala akuntansi perusahaan kemudian dibandingakan dengan literature yang ada. Penerapan metode biaya berdasarkan aktivitas (ABC) memberikan dampak yang sangat baik dalam meningkatkan efiensi dan aktivitas sumber daya. Perhitungan biaya dangan ABC mampu menghasilkan biaya yang lebih murah dan lebi akurat bila dibandingkan dengan pendekatan tradisional. Pada akhirnya Rumah Sakit Siloam di Manado mampu menyediakan tarif yang terjangkau pada pasien.
\end{abstract}

Kata kunci: akuntansi biaya, perhitungan biaya metode tradisional, perhitungan biaya berdasarkan aktivitas.

\begin{abstract}
This research compared the traditional method of cost calculation with activity based costing $(A B C)$ in determining the inpatient room rate at Siloam Hospital. This research uses descriptive analytical method. Data obtained by analyzing documents, participant observation, interviews with chief accounting company then comparated with the existing literature. Implementation of activity based costing $(A B C)$ provides an excellent effect in improving efficiency and resource activities. Calculation of costs with ABC is able to produce cheaper and more accurate when compared with traditional approaches. In the end Siloam Hospital is able to provide affordable rates for patients.
\end{abstract}

Keywords: accounting cost, traditional costing method, activity based costing. 


\section{Latar Belakang}

\section{PENDAHULUAN}

Regionalisasi ekonomi di Asia Tenggara dan kemunculan Asia Free Trade Area (AFTA) sejak tahun 1980-an, telah terjadi serangkaian perubahan fundamental di dunia, antara lain:

1. Munculnya lingkungan ekonomi dunia yang kompetitif dan terjadinya perubahan cepat menuju ekonomi berorientasi pasar khususnya di Eropa eks-sosialis dan juga di Asia yang ditandai dengan adanya reformasi ekonomi melalui privatisasi, deregulasi dan liberalisasi.

2. Terjadinya revolusi teknologi informasi yang memungkinkan peningkatan secara luar biasa transaksi perdagangan dan saling ketergantungan antar negara di dunia.

3. Meningkatnya regionalisasi yang ditandai dengan munculnya pengaturan perdagangan dan investasi dalam lingkup regional di berbagai belahan dunia.

Berbagai kecendurungan tersebut kemudian mendorong para pemimpin negara Asia, khususnya negaranegara anggota ASEAN, untuk mendirikan suatu organisasi ekonomi regional di Asia Tenggara. Setelah melalui serangkaian negonisasi dan perdebatan yng panjang. Pada Millenium Summit ke-4 ASEAN di Singapura tahun 1992, ASEAN yang saat itu masih beranggotakan 6 negara (Brunei, Indonesia, Malaysia, Filipina, Singapura, dan Thailand) sepakat membentuk kawasan perdagangan bebas ASEAN (AFTA) dalam rentang waktu 15 tahun dimulai sejak 1 Januari 1993 dan dengan adanya kawasan perdagangan bebas tersebut maka seluruh negara anggota ASEAN akan mengurangi hambatan arus perdagangan dan investasi antara mereka secara bertahap pada tahun 2008 yang di letakan dalam skema Common Effective Preferential Tarif (CEPT). Inti dari CEPT dalam persetujuan AFTA adalah pengurangan berbagai tarif impor dan penghapusan hambatan non-tarif atas perdagangan dalam lingkup ASEAN. Hal ini membawa implikasi bagi indonesia berupa perubahan harga relatif produk-produk indonesia yang di ekspor ke negara-negara ASEAN disamping akan menjadi intensif bagi masuknya investasi asing yang selama ini menjadi salah satu pilar untuk memutar roda perekonomian nasional. Oleh karena itu, dalam hal ini profil perdagangan dan investasi indonesia, dengan perbandingan profil negaranegara anggota lainnya, sangat penting diketahui guna melihat sejauh mana AFTA akan membawa dampak positif bagi indonesia. Pertama dan yang paling penting dalam sistem ekonomi pasar adalah perdagangan (Ariyanto, 2010:3).

\section{Tujuan Penelitian}

Tujuan yang hendak dicapai dari penelitian ini adalah untuk mengetahui apakah metode activity based costing akan menghasilkan perhitungan biaya yang lebih akurat dibandingkan dengan traditional costing method.

\section{Akuntansi Biaya}

\section{TINJAUAN PUSTAKA}

Akuntansi biaya menurut Mulyadi (2005:7) adalah "akuntansi biaya sebagai proses pencatatan, penggolongan, peringkasan, dan penyajian biaya pembuatan dan penjualan produk atau jasa dengan cara-cara tertentu serta penafsiran-penafsiran terhadapnya". Carter dan Usry (2006:11) menyebutkan bahwa "akuntansi biaya melengkapi manajemen dengan alat yang diperlukan untuk aktivitas-aktivitas perencanaan dan pengendalian, memperbaiki kualitas dan efisiensi, serta membuat kepuusan-keputusan yang bersifat rutin maupun strategis"

\section{Klasifikasi Umum Biaya}

Klasifikasi biaya sangat penting guna membuat ikhtisar atas data biaya untuk tujuan penyusunan laporan keuangan, untuk memprediksi perilaku biaya, untuk pembebanan biaya ke objek biaya, serta untuk pembuatan keputusan. Garrison dan Norren (2006:50), mengklasifikasikan biaya sebagai berikut:

a. Biaya produksi (Manufacturing Cost)

Yaitu semua biaya untuk merubah bahan mentah menjadi produk jadi. Biaya ini dikalsifikasikan menjadi:

1) Bahan Langsung

2) Tenaga Kerja Langsung

3) Overhead Pabrik 
a. Biaya Non Produksi (Non-manufacturing)

Umumnya, dibagi menjadi dua yaitu biaya pemasaran dan biaya administrasi. Biaya pemasaran meliputi semua biaya yang diperlukan untuk menangani pesanan konsumen dan memperoleh produk atau jasa untuk disampaikan kepada konsumen.

c. Biaya Variabel

Biaya variabel adalah biaya yang berubah secara proporsional dengan perubahan aktivitas.

d. Biaya Tetap

Biaya tetap adalah biaya yang selalu tetap secara keseluruhan tanpa terpengaruh oleh tingkat aktivitas..

e. Biaya Langsung

Biaya langsung (direct cost) adalah biaya yang dapat ditelusuri dengan mudah ke objek biaya yang bersangkutan.

f. Biaya Tidak Langsung

Biaya langsung (direct cost) adalah biaya yang tidak dapat ditelusuri dengan mudah ke objek biaya yang bersangkutan.

g. Biaya Diferensiasi

Biaya diferensiasi (differential cost) adalah keputusan melibatkan proses pemilihan dari berbagai alternatif yang ada..

h. Opportunity Cost

Biaya kesempatan atau biaya peluang (opportunity cost) adalah manfaat petensial yang akan hilang bial salah satu alternatif telah dipilih sejumlah alternatif yang tersedia.

i.. $\quad$ Sunk Cost

Biaya tertanam (sunk cost) adalah biaya yang telah terjadi dan tidak dapat diubah oleh keputusan apapun yang dibuatsaat ini atau pu masa yang datang. Karena biaya tertanam tidak dapat diubah oleh keputusan apapun, biaya tertanam bukanlah biaya diferensial.

\section{Tradisional Costing Method}

sistem biaya tradisional menurut Bastian dan Nurlela (2009:23) adalah di mana biaya bahan baku langsung, biaya tenaga kerja langsung, biaya overhead pabrik baik yang bersifat variabel maupun tetap, menjadi biaya produk.

\section{Sistem Activity Based Costing}

Bastian dan Nurlela (2009:24) menyatakan activity based costing adalah metode membebankan biaya aktivitas-aktivitas berdasarkan besarnya pemakaian sumber daya, dan membebankan biaya pada objek biaya, seperti produk atau pelanggan, berdasarkan besarnya pemakaian aktivitas, serta untuk mengukur biaya dan kinerja dari aktivitas yang terkait dengan proses dan objek biaya.

\section{Prosedur pembebanan biaya dua tahap}

Pembebanan biaya dua tahap (two stage cost assigment) membebankan biaya sumber daya seperti biaya overhead pabrik ke pusat biaya aktivitas atau tempat penampungan biaya dan kemudian ke objek biaya untuk menentukan jumlah biaya sumber daya bagi setiap objek biaya. Sistem perhitungan biaya berdasarkan tradisional membebankan biaya overhead pabrik pertama, ke tempat penampungan biaya departemen atau pabrik, dan kedua ke produk atau jasa. Meskipum demikian, prosedur pembebanan biaya tradisional kemungkinan mendistorsi biaya produk atau jasa. Distorsi akan semakin serius khususnya ketika bagian yang penting dari biaya overhead pabrik tidak terkait dengan volume outputdan perusahaan memproduksi produk dengan kombinasi yang beragam dengan perbedaan pada volume, ukuran, atau kompleksitas

Sistem activity based costing (ABC) berbeda dari sistem perhitungan biaya tradisional dalam hal menelusuri penggunaan sumber daya pada aktivitas dan mengaitkan biaya aktivitas pada produk, jasa, atau pelanggan (Blocher, 2006:224). Tahap pertama membebankan biaya overhead pabrik ke aktivitas atau pusat biaya aktivitas. Tahap kedua membebankan biaya atau aktivitas dari tempat penampungan biaya aktivitas ke objek biaya dengan menggunakan penggerak biaya konsumsi aktivitas yang tepat yang mengukur permintaan objek biaya yang ditempatkan pada aktivitas atau tempat penampungan aktivitas. Prosedur alokasi dua tahap pada ABC mengidentifikasi dengan jelas biaya-biaya dari aktivitas suatu perusahaan. Pembebanan biaya aktivitas ke objek biaya menggunakan suatu ukuran atau ukuran-ukuran yang mencerminkan permintaan objek 
biaya atas aktivitas perusahaan. Dengan demikian, $\mathrm{ABC}$ melaporkan biaya produk atau jasa dengan lebih akurat dibandingkan dengan sistem biaya tradisional.

\section{Penelitian Terdahulu}

Industry yang akan diteliti pada penelitian ini adalah industry jasa. Industry jasa adalah suatu jenis usaha yang outputnya berupa pelayanan kepada pelanggan.

\section{Tabel 1. Penelitian terdahulu}

\begin{tabular}{|c|c|c|c|c|}
\hline $\begin{array}{c}\text { Peneliti/ } \\
\text { Tahun } \\
\end{array}$ & Judul & Persamaan & Perbedaan & Hasil penelitian \\
\hline $\begin{array}{l}\text { MehmetC. } \\
\text { Kocakulah, } \\
\text { Ph.D.(2007) }\end{array}$ & $\begin{array}{l}\text { Using Activity- } \\
\text { Based costing } \\
\text { (ABC) Measure } \\
\text { Profibility on a } \\
\text { Commercial Loan } \\
\text { Portofolio }\end{array}$ & $\begin{array}{l}\text { Persamaan penelitian } \\
\text { yang dilakukan oleh } \\
\text { Mehmet C. Kocakulah } \\
\text { dengan penelitian } \\
\text { sekarang adalah sama- } \\
\text { sama menggunakan } \\
\text { activity based costing } \\
\text { dalam sistem } \\
\text { perhitungan biaya. }\end{array}$ & $\begin{array}{l}\text { Penelitian yang dilakukan } \\
\text { oleh Mehmet C. kocakulah } \\
\text { dilakukan pada industry } \\
\text { perbankan sedangkan } \\
\text { penelitian sekarang } \\
\text { dilakukan pada industry } \\
\text { jasa }\end{array}$ & $\begin{array}{l}\text { ABC mampu } \\
\text { memberikan } \\
\text { informasi yang } \\
\text { akurat mengenai } \\
\text { biaya dan } \\
\text { profitabilitas, } \\
\text { sehingga } \\
\text { manajemen dapat } \\
\text { mengambil } \\
\text { keputusan untuk } \\
\text { meningkatkan } \\
\text { keuntungannya }\end{array}$ \\
\hline $\begin{array}{l}\text { Nunik } \\
\text { L.D.(2007) }\end{array}$ & $\begin{array}{l}\text { ABC Sistem: } \\
\text { Sistem Biaya } \\
\text { Dalam Mengatasi } \\
\text { Kelemahan/ } \\
\text { Kekurangan Sistem } \\
\text { Biaya Tradisional }\end{array}$ & $\begin{array}{l}\text { Menggunakan variable } \\
\text { activity based costing } \\
\text { dan traditional costing } \\
\text { consept. }\end{array}$ & $\begin{array}{l}\text { Penelitian Nunik adalah } \\
\text { penelitian kepustakaan } \\
\text { sedangkan penelitian } \\
\text { sekarang adalah penelitian } \\
\text { lapangan pada dua jenis } \\
\text { industri yang berbeda }\end{array}$ & $\begin{array}{l}\text { ABC sistem } \\
\text { membantu } \\
\text { sistem biaya } \\
\text { tradisional } \\
\text { dalam } \\
\text { menentukan } \\
\text { biaya } \\
\text { overhead agar } \\
\text { lebih tepat dan } \\
\text { akurat yaitu } \\
\text { dengan cara } \\
\text { penentuan } \\
\text { biaya atas } \\
\text { dasar aktivitas } \\
\text { yang } \\
\text { dilakukan } \\
\text { untuk } \\
\text { menghasilkan } \\
\text { produk dan } \\
\text { jasa }\end{array}$ \\
\hline $\begin{array}{l}\text { Cheisvyany } \\
(2007)\end{array}$ & $\begin{array}{l}\text { Penerapan Activity } \\
\text { Based Costing } \\
\text { Untuk Analisis } \\
\text { Profitabilitas } \\
\text { Pelanggan }\end{array}$ & $\begin{array}{l}\text { Menggunakan activity } \\
\text { based costing untuk } \\
\text { membebankan biaya } \\
\text { aktivitas pada produk. } \\
\text { Persamaan lainnya ialah } \\
\text { menggunakan metode } \\
\text { field research. }\end{array}$ & $\begin{array}{l}\text { Penelitian Charoline } \\
\text { membahas tentang } \\
\text { penerapan ABC } \\
\text { pengaplikasian konsep } \\
\text { customer relationship } \\
\text { management (CRM) dalam } \\
\text { menganalisa profitabilitas. }\end{array}$ & $\begin{array}{l}\text { Secara jangka } \\
\text { panjang } \\
\text { analisis ini } \\
\text { dapat } \\
\text { memberikan } \\
\text { future growth } \\
\text { bagi } \\
\text { perusahaan } \\
\text { dengan } \\
\text { pencapaian } \\
\text { visi dan misi }\end{array}$ \\
\hline
\end{tabular}




$\begin{array}{lll}\text { Widyaningsih } & \text { Peranan dan } & \text { Meneliti peranan ABC } \\ \text { (2009) } & \text { Kendala Penerapan } & \text { pada industry jasa } \\ & \text { Activity Based } & \\ & \text { costing (ABC) } & \\ & \text { dalam Industry Jasa } & \end{array}$

$\begin{array}{ll}\text { Penelitian Aristanti } & \text { intinya dapat } \\ \text { menggunakan activity } & \text { disimpulkan } \\ \text { based management, total } & \text { bahwa ABC } \\ \text { quality of management, } & \text { tidak hanya } \\ \text { serta strategi kualitas untuk } & \text { dapat } \\ \text { mendukung penelitian } & \text { diterapkan } \\ \text { ABC nya } & \text { pada } \\ & \text { perusahaan } \\ & \text { manufaktur } \\ & \text { tetapi juga } \\ & \text { dapat } \\ & \text { diterapkan } \\ & \text { pada industry } \\ & \text { jasa. }\end{array}$

\section{METODE PENELITIAN}

\section{Jenis Penelitian}

Jenis penelitian pada penelitian ini adalah studi komparatif tentang penerapan traditional costing concept dengan activity based costing (ABC) pada jenis industri jasa. Industri jasa yang akan diteliti adalah RS. Siloam di Manado yang beralamat di Jl. Samrat No. 22 Manado dengan objek penelitian penentuan tarif kamar rawat inap. Data yang dibutuhkan untuk penelitian $\mathrm{ABC}$ ini adalah laporan laba rugi untuk tahun yang berakhir 31 Desember 2012, direct cost, direct labor, dan biaya overhead yang terkait dengan kamar rawat.

\section{Tempat dan Waktu Penelitian}

Tempat dan waktu yang menjadi penelitian ini adalah Rumah Sakit Siloam Manado yang bertempat di Jl. Samrat No. 22 Manado. Waktu dalam melakukan penelitian ini adalah 2 bulan yaitu dari bulan oktober sampai dengan November 2013.

\section{Prosedur Penelitian}

Prosedur penelitian yang di lakukan adalah sebagai berikut :

a. Survey objek penelitian.

b. Mengambil data-data perusahaan dan wawancara.

c. Membandingkan dan mengolah data-data dan informasi perusahaan dengan dasar teori yang di gunakan.

d. Membuat kesimpulan dan memberikan saran.

\section{Metode Pengumpulan Data}

Metode penelitian yang digunakan adalah penelitian analisis Deskiptif. Peneliti menganalisa seluruh data yang relevan dengan objek penelitian, baik itu catatan berupa hasil interview, dokumen serta laporan- laporan yang diberikan oleh perusahaan. Saat melakukan interview, observasi, dan analisis dokumen, peneliti melakukan pertanyaan-pertanyaan yang mearahkannya untuk mengambil data yang diperlukan serta data didapatkan kembali dibandingkan dengan teori (theoritical comparison)yang digunakan dan ditariklah suatu kesimpulan sebagai hasil penelitian.

\section{Teknik Pengumpulan Data}

Proses penelitian dan penulisan skripsi ini, penulis menggunakan metode pengumpulan data adalah sebagai berikut:

1. Interview/wawancara

2. Observas.

3. Analisis Dokumen

\section{Metode Analisa Data}


Metode penelitian yang digunakan adalah penelitian analisis Deskiptif. Peneliti menganalisa seluruh data yang relevan dengan objek penelitian, baik itu catatan berupa hasil interview, dokumen serta laporan- laporan yang diberikan oleh perusahaan.

\title{
Sejarah Singkat Rumah Sakit Siloam Manado
}

\section{HASIL PENELITIAN DAN PEMBAHASAN}

Dibuka pada tahun 2012, SHMN adalah rumah sakit swasta terkemuka di Manado, Sulawesi Utara. Terletak di Central Business District di Manado, SHMN dapat dengan mudah diakses oleh transportasi umum. Karena lokasi utama, SHMN adalah tujuan pelayanan kesehatan untuk seluruh tenaga kerja perusahaan serta wisatawan dan warga sipil di Manado

\author{
Visi dan Misi Rumah Sakit Siloam \\ Our Vision: \\ International Quality, Scale, Reach, Godly Compassion. \\ Our Mission: \\ The trusted destination of choice for holistic world class healthcare, health education and research.
}

\section{Hasil Penelitian}

Rumah sakit siloam adalah salah satu rumah sakit swasta yang memberikan palayanan kesehatan yang berkualitas, lengkap, dan terjangkau karena rumah sakit siloam tedak hanya memiliki fungsi komersial tetapi juga mengutamakan fungsi sosialnya. Ini merupakan tantangan bagi rumah sakit untuk dapat memberikan pelayanan yang maksimal dengan biaya yang seminimal mungkin khususnya mengenai pelayanan rawat inap.

Tabel 2. Perhitungan Tarif Kamar Rawat Inap Menggunakan Activity Based Costing

\begin{tabular}{|c|c|c|c|c|}
\hline Keterangan & VIP & Kelas I & Kelas II & Kelas III \\
\hline \multicolumn{5}{|l|}{ DIRECT } \\
\hline \multicolumn{5}{|l|}{ COST } \\
\hline Bahan medis & Rp. $1,828.57$ & Rp. $1,799.43$ & Rp. 1,463.21 & Rp. 880.53 \\
\hline pasien & Rp. 31.593.00 & Rp. 31,593.00 & Rp. $24,745.00$ & Rp. $20,305.00$ \\
\hline Total direct cost & Rp. 33,421.57 & Rp. 33,392.43 & Rp. 26,208.21 & Rp. 66,513.53 \\
\hline \multicolumn{5}{|l|}{ DIRECT LABOR } \\
\hline $\begin{array}{l}\text { Gaji dan tunjangan } \\
\text { perawat }\end{array}$ & Rp. $182,224.08$ & Rp. $137,817.72$ & Rp. $215,260.80$ & Rp. $135,427.20$ \\
\hline Total direct labor & Rp. $182,224.08$ & Rp. $137,817.72$ & Rp. $215,260.80$ & Rp. $135,427.20$ \\
\hline \multicolumn{5}{|l|}{ OVERHEAD } \\
\hline $\begin{array}{l}\text { Registrasi } \\
\text { pasien }\end{array}$ & Rp. $2,878.42$ & Rp. $2,370.56$ & Rp. 862.58 & Rp. $1,021.57$ \\
\hline $\begin{array}{l}\text { Keterangan } \\
\text { OVERHEAD }\end{array}$ & VIP & Kelas I & Kelas II & Kelas III \\
\hline Desain layanan & Rp. $1,930.85$ & Rp. $1,815.18$ & Rp. $1,528.17$ & Rp. 3,610.63 \\
\hline $\begin{array}{l}\text { Pelayanan } \\
\text { pasien }\end{array}$ & Rp. 7,199.17 & Rp. 6,761.96 & Rp. $5,167.74$ & Rp. 4,664.82 \\
\hline Total overhead & Rp. 12,008.44 & $\begin{array}{l}\text { Rp. 10,947.69 } \\
\text { Rp. }\end{array}$ & Rp. 7,558.49 & Rp. 9,297.02 \\
\hline COGS & Rp. 227,654.0859 & $182,157.8415$ & Rp. 249,027.5026 & Rp. 165,909.5461 \\
\hline inflasi $10 \%$ & Rp. $22,765.40$ & Rp. 18,215.78 & Rp. $24,902.75$ & Rp. $16,590.95$ \\
\hline Margin kontribusi & Rp. $68,296.224$ & $\begin{array}{l}\text { Rp. } 54,647.352 \\
\text { Rp. }\end{array}$ & Rp. $62,256.875$ & Rp. 33,181.908 \\
\hline Tarif & Rp. 318,715.7099 & $255,020.9735$ & Rp. 336,187.1276 & Rp. 215,682.1041 \\
\hline
\end{tabular}

Sumber data di olah 
Tabel 3. Direct Cost, Direct Labor, Overhead Per Hari Per Ruang Perawatan Dengan Menggunakan Traditional Costing Method

\begin{tabular}{|c|c|c|c|c|}
\hline Keterangan & VIP & Kelas I & Kelas II & Kelas III \\
\hline \multicolumn{5}{|l|}{ DIRECT COST } \\
\hline Bahan medis & Rp. $1,828.57$ & Rp. $1,799.43$ & Rp. 1,463.21 & Rp. 880.53 \\
\hline $\begin{array}{l}\text { Makan dan } \\
\text { minum pasien }\end{array}$ & Rp. $31,593.00$ & Rp. $31,593.00$ & Rp. $24,745.00$ & Rp. $20,305.00$ \\
\hline $\begin{array}{l}\text { Total direct cost } \\
\text { DIRECT }\end{array}$ & Rp. 33.421 .57 & Rp. $33,392.43$ & Rp. 26,208.21 & Rp. $21,185.53$ \\
\hline$L A B O R$ & & & & \\
\hline $\begin{array}{l}\text { Gaji dan } \\
\text { tunjangan } \\
\text { perawat }\end{array}$ & Rp. $182,224.08$ & Rp. $137,817.72$ & Rp. $215,260.80$ & Rp. $135,427.20$ \\
\hline $\begin{array}{l}\text { Total direct } \\
\text { labor }\end{array}$ & Rp. $182,224.08$ & Rp. $137,817.72$ & Rp. $215,260.80$ & Rp. $135,427.20$ \\
\hline $\begin{array}{l}\text { OVERHEAD } \\
\text { Beban } \\
\text { penyusutan } \\
\text { perawatan }\end{array}$ & Rp. $46,964.38$ & Rp. $44,293.15$ & Rp. 35,663.01 & Rp. 30,320.54 \\
\hline Linen & Rp. 1,988.77 & Rp. $108,854.00$ & Rp. 1,331.61 & Rp. 626.73 \\
\hline $\begin{array}{l}\text { Biaya pemakaian } \\
\text { perlengkapan }\end{array}$ & Rp. 7,702.38 & Rp. 7,599.43 & Rp. 6,922.07 & Rp. 6,359.91 \\
\hline $\begin{array}{l}\text { Gas loundry dan } \\
\text { bahan }\end{array}$ & Rp. 4,778.91 & Rp. 549.55 & Rp. 579.29 & Rp. 506.42 \\
\hline Kebersihan & Rp. 4,268.97 & Rp. 6,990.44 & Rp. $1,999.73$ & Rp. 5,873.32 \\
\hline $\begin{array}{l}\text { Biaya } \\
\text { pemeliharan }\end{array}$ & Rp. $1,142.85$ & Rp. 1,934.52 & Rp. $1,345.13$ & Rp. 600.00 \\
\hline $\begin{array}{l}\text { Biaya material } \\
\text { unit }\end{array}$ & Rp. 45.31 & Rp. 753.96 & Rp. 581.87 & Rp. 106.61 \\
\hline Biaya listrik & Rp. 1,886.74 & Rp. 1,453.22 & Rp. 1,630.62 & Rp. 934.47 \\
\hline Total overhead & Rp. 68,778.31 & Rp. 64,662.81 & Rp. 50,033.33 & Rp. 45,328.00 \\
\hline COGS & Rp. 284.423 .96 & Rp. $235,872.96$ & Rp. 291,502.34 & Rp. $201,940.73$ \\
\hline
\end{tabular}

Sumber: Data di olah

Perbandingan Tarif Kamar Rawat Inap Antara Pendekatan Saat Ini (Tradisional Costing Method), dan Activity Based Costing.

Seperti yang telah dijelaskan sebelumnya, bahwa Rumah Sakit Siloam memiliki perhitungan baku dalam menetapkan sebuah tarif kamar rawat. Dibawah ini adalah perhitungan tarif berdasarkan tradisional costing method. Perusahaan hanya melakukan estimasi apakah pendapatan dari sewa kamar mampu menanggung seluruh beban yang dikeluarkan. Berdasarkan perhitungann dan analisa yang telah dilakukan dengan metode tradisional dan $\mathrm{ABC}$ maka hasil akhir dari penelitian ini adalah $\mathrm{ABC}$ terbukti mampu memberikan perhitungan tarif yang lebih murah dibandingkan dengan metode tradisional. Dibawah ini adalah tabel yang menunjukan perbandingan antara kedua pendekatan, yaitu pendekatan saat ini dan pendekatan $\mathrm{ABC}$.

Tabel 4. Perbandingan Tarif Kamar Rawat Inap Antara Pendekatan Saat Ini (Traditional Costing Method), dan Activity Based Costing Kamar Rawat

\begin{tabular}{lllc}
\multicolumn{1}{c}{ Inap } & \multicolumn{1}{c}{ Existing } & \multicolumn{1}{c}{ ABC } & Kenaikan/penurunan \\
\hline VIP & Rp. 550,000.00 & Rp. 318,715.71 & Naik \\
KELAS I & Rp. 425,000.00 & Rp. 225,020.91 & Naik \\
KELAS II & Rp. 300,000.00 & Rp. 336,187.13 & Turun \\
KELAS III & Rp. 100,000.00 & Rp. 215,682.40 & Turun \\
\hline
\end{tabular}

Sumber: data di olah 
Tabel di atas menggambarkan secara jelas bahwa sistem activity based costing mampu menyajikan perhitungan lebih akurat dan lebih murah dari metode tradisional.

\section{Pembahasan}

Hasil akhir dari penelitian ini adalah sistem activity based costing (ABC) terbukti mampu memberikan perhitungan tarif yang lebih murah dibandingkan dengan metode tradisional. Berdasarkan hal tersebut, penerapan system $\mathrm{ABC}$ di rumah sakit siloam ini masih dapat memberikan manfaat yang dirasakan oleh manajemen, walaupun itu akan mempengaruhi aspek budaya dan keuangan perusahaan. Ditinjau dari aspek budaya, system ABC dengan konsep value added-nya akan merombak budaya. Selama ini kebijakan perusahaan dalam menetapkan tarif kamar rawat inap hanya berdasarkan analisa semata, tanpa menghitung biaya yang memang seharusnya dibebankan ke pasien. Oleh karena itu, hasil tarif yang ditetapkan manajemen selama ini menjadi tidak akurat, yang pada akhirnya menetapkan perusahaan pada posisi yang kurang memuaskan dalam daya saing masyarakat. Dari aspek keuangan, menyangkut cost of implementation dari ABC sendiri yang meliputi perancangan sistem baru, pendidikan dan training tentang sistem baru. Tentunya selain cost, benefit yang akan diterima dari penerapan $\mathrm{ABC}$ juga harus dihitung. Cost mungkin dapat dihitung dengan segera, tetapi benefit baru dirasakan 5 tahun yang akan datang.

\section{PENUTUP}

\section{Kesimpulan}

Berdasarkan data yang diperoleh dan penelitian lebih lanjut, dapat diambil kesimpulan bahwa Perhitungan tarif kamar dengan menggunakan $\mathrm{ABC}$ terbukti mampu menghasilkan biaya yang lebih murah bila dibandingkan dengan pendekatan tradisional. Perlu diingat, bahwa rumah sakit adalah organisasi sosial yang tidak berorientasi pada keuntungan sehingga pada akhirnya penyediakan tarif yang mampu dijangkau oleh masyarakat golongan ekonomi lemah.

Saran

Berdasarkan kesimpulan dan implikasi di atas, saran-saran yang di ajukan dalam penelitian ini adalah:

1. Diharapkan perusahaan melakukan pengklasifikasian unsur-unsur biaya produksi sesuai dengan kaidah yang berlaku.

2. Diharapkan mengaplikasikan $\mathrm{ABC}$ segera mungkin untuk meningkatkan daya saing perusahaan.

3. Peningkatan peluang kinerja perusahaan, dengan meningkatkan efektivitas dan efisiensi penggunaan sumber daya yang terkait dengan tarif kamar rawat.

4. Diharapkan penelitian ini dikembangkan dengan variabel yang berbeda.

\section{DAFTAR PUSTAKA}

Aristanti, Widyaningsih,"Peranan dan Kendala Penerapan Activity Based Costing (ABC) Dalam Industri Jasa", Percikan, Vol 103, Edisi Agustus, 2009.. http://isjd.pdii.lipi.go.id/index.php/Search.html?act=tampil\&id=70736\&idc=28. Tanggal akses: 25 oktober 2013.

Bastian, Bustami.,Nurlela. 2009. Akuntasi Biaya. Mitra Wacana Media. Jakarta.

Blocher, Chen., Cokins., Lin. 2006. Cost Management. Management Biaya Penekanan Strategis. Buku 1. Edisi 3. Salemba Empat.Jakarta.

Blocher, Stout, Cokins, Chen,"Cost Management. A Strategic Emphasis”. Internasional Edition, Mc. Graw Hill Companies, Ins, New York, 2008.

Carter, Usry.2006. Akuntansi Biaya. Edisi 13.Salemba Empat. Jakarta.

Carter, William K, Akuntansi Biaya. Buku 1, Edisi 14, Salemba Empat, Jakarta, 2009.

Charoline, Cheisviyanny, Penerapan Activity Based Costing Untuk Analisis Pelanggan. Jurnal Economic, Vol 7, April, Hal. 39-44, 2007. 
http://isjd.pdii.lipi.go.id/index.php/Search.html?act=tampil\&id=75454\&idc=28. Tanggal akses: 19 oktober 2013

Garrison, Noreen., brewer.2006. Managerial Accounting. Edisi 11. Salemba Empat. Jakarta.

Mehmet C. Kocakulah., Ph.D. Using Activity-Based Costing (ABC) to Measure Profitability on a commercial Loan Portofolio. Journal of Performance Management. ABI/INFORM Global pg. 29. 2007.

Mulyadi. 2009. Akuntansi Biaya. Edisi 5. Universitas Gajah Mada. Yogyakarta.

Nunik, L. ABC System: Sistem Biaya Dalam Mengatasi Kelemahan/Kekurangan Sistem Biaya Tradisional. Jurnal Ilmiah Akuntansi. Vol 6. no. 2 November. Hal. 88-100, 2007.

http://repository.ipb.ac.id/bitstream/handle/123456789/47731/h11waw. Tanggal akses: 25 oktober 2013 